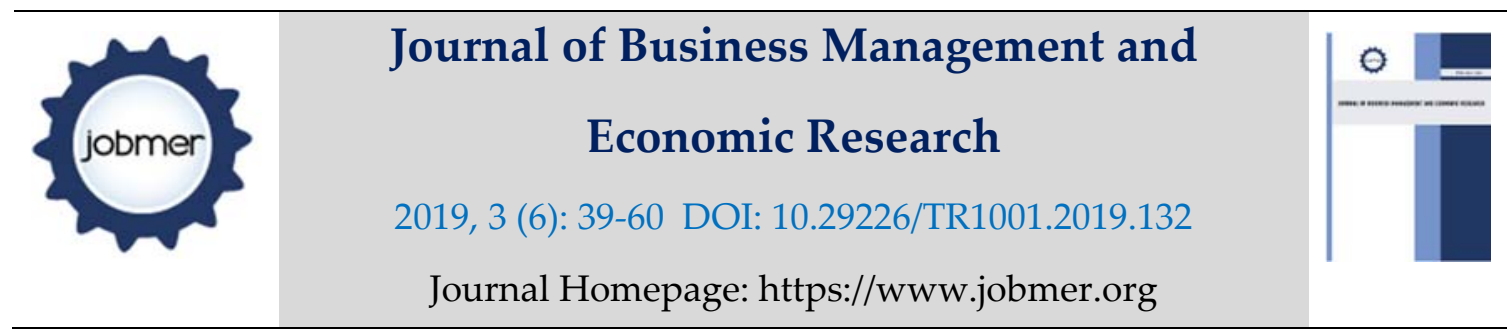

\title{
The Role of Differentiation Strategy and Innovation in Mediating Market Orientation and the Business Performance
}

\section{Gusti Ayu Ketut Giantari}

Faculty of Economics and Bussiness, Udayana University, Bali, Indonesia ayugiantari@gmail.com

\section{Made Jatra}

Faculty of Economics and Bussiness, Udayana University, Bali, Indonesia

\begin{abstract}
Nowadays, SME have a very strategic role. The SME have a large potential in driving the economy and become the source of income which improves the welfare of the people. Thus, it is very important for the government to provide attention to the SME. However, the textile SME in Bali have experienced a fluctuation in business performance. The cause is that the business strategy is not optimal yet. This research has an aim to determine the influence of market orientation on business performance mediated by the differentiation and innovation strategy of the textile SME in Bali. The research is conducted on the textile industry in Bali with a total of 60 units. The total population sampling technique is used, which means that the entire population is included as the sample. The respondents are the entrepreneurs or owners of the textile businesses distributed in the 9 regencies/cities in Bali. The data analysis technique used is the SEM based on the PLS (Partial Least Square). The research result shows that market orientation has a positive and significant influence on business performance, differentiation and innovation strategy. Differentiation strategy has a positive and significant influence on business performance. Innovation strategy has a positive and significant influence on business performance. The differentiation and innovation strategy variable is able to partially mediate the relationship between market orientation and business performance.
\end{abstract}

Keyword : Market Orientation, Differentiation Strategy, Innovation Strategy and Business Performance 
Journal of Business Management and Economic Research (JOBMER), vol.3, issue.6, pp.39-60

\section{Introduction}

In general, $\mathrm{t}$ is very important for the government to provide attention for the SME because of the SME have a large potential in driving the economy and becoming the income source to improve the welfare of the people. The performance of SME in Bali has fluctuated from 2012 until 2016 with an average increase of 8,54\% (Dinas Perindustrian dan Perdagangan Provinsi Bali, 2016) but has also experienced a drastic fall in 2015 at a magnitude of 15,73\%. Among the affected SME are the textile industry SME.

One of the cause of the fall in performance is the high competition, thus it is important for marketers to perform market orientation. Market orientation is the firm's culture in providing customer value to customers, which is expected to improve business performance. Business performance is the firm's performance which is measured using sales volume, market share and financial performance (AlRfou, 2012 and Guo, 2002). There are some studies that have reviewed the relationship between market orientation and firm performance (Lin et al., 2008, Nasution et al., 2011 and Alam, 2013) and showed that market orientation, which includes competitor orientation, customer orientation, and coordination between functional, has a positive and significant influence on company performance. However, Han et al. (1998) stated that market orientation has a positive and insignificant influence on performance. To fill in this research gap, there is a need to add the differentiation and innovation strategy variable to improve the business performance of the SME.

In addition to market orientation, innovation and differentiation are also firm strategies used to improve business performance. Innovation strategy is the ability of the firm to discover new ideas in providing innovative products. The influence of innovation strategy on business performance has been studied by other researchers, among others, Hult et al., 2004, Hilmi et al., 2010, Rhee et al., 2010, who revealed that innovation has a positive and significant influence on business performance.

Differentiation is among the important alternative strategies in improving business performance. For the textile SME, differentiation can be conducted by offering unique, competitive and advanced products. Research regarding the influence of differentiation on business performance have been conducted by several researchers, among others Destyanti (2007), Tampi (2015) Haksama (2014), and Setiawan (2016), that have found that differentiation has a positive and significant influence on business performance. Based on the discussions above, it is important to examine the role of 
differentiation and innovation strategy in mediating the relationship between market orientation and business performance.

\section{Literature Review}

\subsection{Market Orientation}

Market orientation is an effective and efficient organizational culture to create the behaviors needed to create superior value for buyers and superior performance for the company. Market orientation is a corporate culture that can lead to increased marketing performance (Kohli and Jaworski, 1990: 18). Narver and Slater (1990: 21) define market orientation as the organizational culture that is most effective in creating important behaviors for the creation of superior value for buyers and performance in business. Market orientation is based on the performance of a company, this performance is based on the results of evaluations and reviews from the company on what has been done by the company (Tjiptono, 2008: 104). Narver and Slater (1990: 21-22) say that market orientation consists of 3 components of behavior namely customer orientation, competitor orientation and interfungional coordination.

Customer orientation and competitor orientation including all of its activities are involved in obtaining information about buyers and competitors in the intended market and disseminating through business, while interfunctional coordination is based on customer information and competitors and consists of coordinated business ventures. Based on a review of various literatures on market orientation theories, it can be said that market orientation is very important as a corporate culture that places the market as the key to the survival of the company. Therefore, to maintain the company's growth rate in the midst of intense competition, the market must be managed optimally with systematic efforts and information on customer needs so as to provide satisfaction to customers. The characteristics and background of the customer need to be identified more deeply so that anticipation of the market can be done well. In particular, companies must serve well and be responsive to the demands of customers and competitors. Based on this, market orientation is seen as a corporate culture that has a customer orientation, competitor orientation, and coordination between functions. 
Journal of Business Management and Economic Research (JOBMER), vol.3, issue.6, pp.39-60

\subsection{Customer Orientation}

Customer orientation (customer orientation) is the highest priority in terms of providing superior values to customers in research conducted assuming customer orientation is the most fundamental thing for the company. Customers are the most important side of the company to determine customer orientation.

Customer orientation (customer orientation) can also be interpreted as an understanding of the target for the buyer that covers all the value of the buyer chain, both what is needed now and the needs in the future. Understanding like this can be used as a basis for sellers to understand who their potential customers are and know their desires in the present and in the future.

Competitive Orientation (competitor orientation) Competitor orientation means that the company understands the short-term strengths, weaknesses, long-term capabilities, and strategies of its potential competitors (Never and Slater, 1990). Competitor-oriented companies are often seen as companies that have strategies and understand how to obtain and share information about competitors, how to respond to competitors 'actions, and also how top management responds to competitors' strategies (Jaworski and Kohli, 1993). Orientation to competitors can be assumed that salespeople will attempt to gather information about competitors and share that information with other functions within the company, for example to the research and product development division or discuss with company leaders how competitor strengths and strategies are developed (Ferdinand, 2000)

\subsection{Interfunctional coordination}

Interfunctional coordination identifies the capabilities needed by the organization in order to form a value chain which includes the main activities and supporting activities (Zhou et al., 2005). Coordination between functions within the organization must be directed towards understanding customer needs by providing the best value compared to its competitors so that customers get satisfaction. The company must have the ability to integrate all functions to be able to work together to present the best value for its customers. Business Performance Business performance is a factor commonly used to measure the impact of a company's strategy. The company's strategy is always directed to produce good performance in the form of marketing performance and financial performance (Ferdinand, 2000). Marketing performance is one concept that can measure market 
performance of a product. The company can see its performance both internally and externally that can be known from the market achievements of its products. Externally, an increase in company performance can be done using a market oriented approach. This is to be able to understand market needs, desires and demands.

\subsection{Business Performance}

Business performance is a general factor used to measure the impact of a firm strategy. The company's strategy will always be directed towards good performance results in the form of marketing performance or financial performance (Ferdinand, 2000). Marketing performance is among the concepts that can measure the market achievements of a product. Companies may assess their internal or external performance by determining the market achievement of their products. Externally, company performance can be improved by using market-oriented approaches. This is to understand the needs, wants, and demand of the market. Market orientation has an important role in improving the company's performance.

\subsection{Differentiation Strategy}

To avoid the trap of commodity, marketers must start with the belief that they can differentiate anything. According to Kotler and Keller (2012), the dimensions used by companies to differentiate their market offers are: product differentiation, personnel differentiation, distribution differentiation, and image differentiation.

\subsection{Innovation Strategy}

Innovation refers to the ability of an organization in adopting or implementing new ideas, process, or successful products (Nasution et al., 2011). Innovation is also related to breakthroughs of new products and ideas or processes. Innovation allows the acceptance of new ideas as a cultural aspect, and the attempt to search for new ways to perform operational activities. Innovation produces creative ideas related to operational methods. Companies are demanded to be able to create new insights, new ideas, offer innovative products, and improve services which will satisfy customers. 
Journal of Business Management and Economic Research (JOBMER), vol.3, issue.6, pp.39-60

According to Hilmi (2010), innovation is the change in the method to conduct business, making it more effective by changing the organizational structure, policies, work method, and production procedure, to make costing and marketing of a product or service become more effective. Innovation also includes changes that affect policies, resource allocation, and other factors related to the social structure of the organization. Innovation is more of an organizational culture aspect which reflects the level of acceptance towards new ideas, reward workers with new ideas, learning ability, and implementation or actualization of the ideas (Rhee et al., 2010).

\section{Hypothesis}

\section{1 The Influence of Market Orientation on Business Performance}

Market orientation has a purpose to determine the direction and provide information regarding the market to create superior value for customers. Market orientation influences market performance, especially for service companies such as five star hotels. Companies must be more sensitive to the market condition in order to provide the best quality for their customers.

For industries in the service sector, service quality becomes an important matter which must be given attention. According to Tjiptono (2008: 30), the definition of service quality is focused on the effort to fulfill the needs and wants of customers and the accuracy of its execution in meeting customer expectations.

Pribadiyanto et al. (2004) stated that an increase in the company's market orientation, which is reflected in customer orientation, distribution of market information and interfunctional coordination, will have a positive influence on the service quality of the company. The studies by Baker and Sinkula (1999), Lin et al. (2008), Nasution et al. (2011) and Alam (2013) stated that market orientation has a significant relationship with firm performance. From these research results, the hypothesis is formulated as follows:

$\mathrm{H}_{1}$ : Market orientation has a positive and significant influence on business performance 


\subsection{The Influence of Market Orientation on Differentiation Strategy}

Market orientation is the measurement of behavior and activity which reflects the implementation of the marketing concepts (Tjiptono and Chandra, 2012). The marketing concept and market orientation is viewed as one of the main marketing management focuses. If the marketing concept is viewed as a philosophy positioned as one of the main parts of the firm culture, market orientation can be viewed as the implementation of the marketing concepts. Thus, organizations with market orientation are organizations that consistently implement the marketing concepts (Kohli and Jaworski, 1990). Meanwhile, Narver and Slater (1990) defined market orientation as the most effective and efficient organizational culture in forming the behaviors needed to create superior value for the buyers and produce superior performance for the company.

$\mathrm{H}_{2}$ : Market orientation has a positive and significant influence on differentiation strategy.

\subsection{The Influence of Market Orientation on Innovation Strategy}

Related with the relationship between market orientation and innovation, O'Cass and Ngo (2011) found that market orientation has an influence on the company's innovation. Furthermore, Baker and Sinkula (1999) stated that market orientation is needed to create an optimal environment for innovation. Mavondo et al., (2005) identified innovation as the consequence of market orientation. Nasution et al. (2011) and Rahab (2012) added that by integrating market orientation, companies will be able to increase innovation. This means that having a deep understanding of the needs of customers will allow the organization to improve their innovation culture. Based on the reviews above, the hypothesis proposed is as follows:

$H_{3}$ : Market orientation has a positive and significant influence on innovation strategy

\subsection{The Influence of Differentiation Strategy on Business Performance}

Destyanti's (2007) research results showed that the differentiation strategy implemented by Telkomsel Limited Company was able to increase their business performance, in which the number of customers and revenue increased. Kotler and Keller (2012) stated that differentiation strategy which consists of product differentiation, price differentiation, distribution differentiation and image 
differentiation is able to improve firm performance. Tampi (2015), Haksama (2014), and Setiawan (2016) stated that differentiation strategy has a positive and significant influence on business performance. Thus, the hypothesis proposed is as follows:

$H_{4}$ : Differentiation Strategy has a positive and significant influence on business performance

\subsection{The Influence of Innovation Strategy on Business Performance}

Innovation is the ability of organizations to adopt new ideas, products and services. When companies frequently try new ideas, the company will be more able to provide innovative products, which will result in sales volume growth, asset growth, and market share growth (Ndubisi and Iftikhar, 2012). Thus, the increase in the firm's ability to perform innovation will result in an increase in business performance. There are several studies that show that innovation has a positive and significant influence on business performance (Hult et al., 2004, Hilmi et al., 2010 and Rhee et al., 2010). Based on previous research results, the hypothesis formulated is as follows:

$H_{5}$ : Innovation strategy has a positive and significant influence on business performance

3.6 The Role of Differentiation Strategy in Mediating the Relationship between Market Orientation and Business Performance

Market orientation has a positive and significant influence on differentiation strategy (Kohli and Jaworski, 1990, and Narver and Slater, 1990). Differentiation has a positive and significant influence on business performance (Destyanti, 2007, Kotler and Keller, 2012). Thus, the research hypothesis formulated is:

$\mathrm{H}_{6}$ : Differentiation strategy is able to mediate the relationship between market orientation and business performance 
3.7 The Role of Innovation Strategy in Mediating the Relationship between Market Orientation and Business Performance

Market orientation has a positive and significant influence on innovation strategy (Baker and Sinkula,1999; Mavondo et al., 2005 ; Nasution et al.,2011 and Rahab, 2012). While innovation has a positive and significant influence on business performance (Hilmi et al., 2010 and Rhee et al., 2010). Thus, the research hypothesis formulated is:

$\mathrm{H}_{7}$ : Innovation strategy is able to mediate the relationship between market orientation and business performance

The conceptual framework of this research is presented in Figure 1 below.

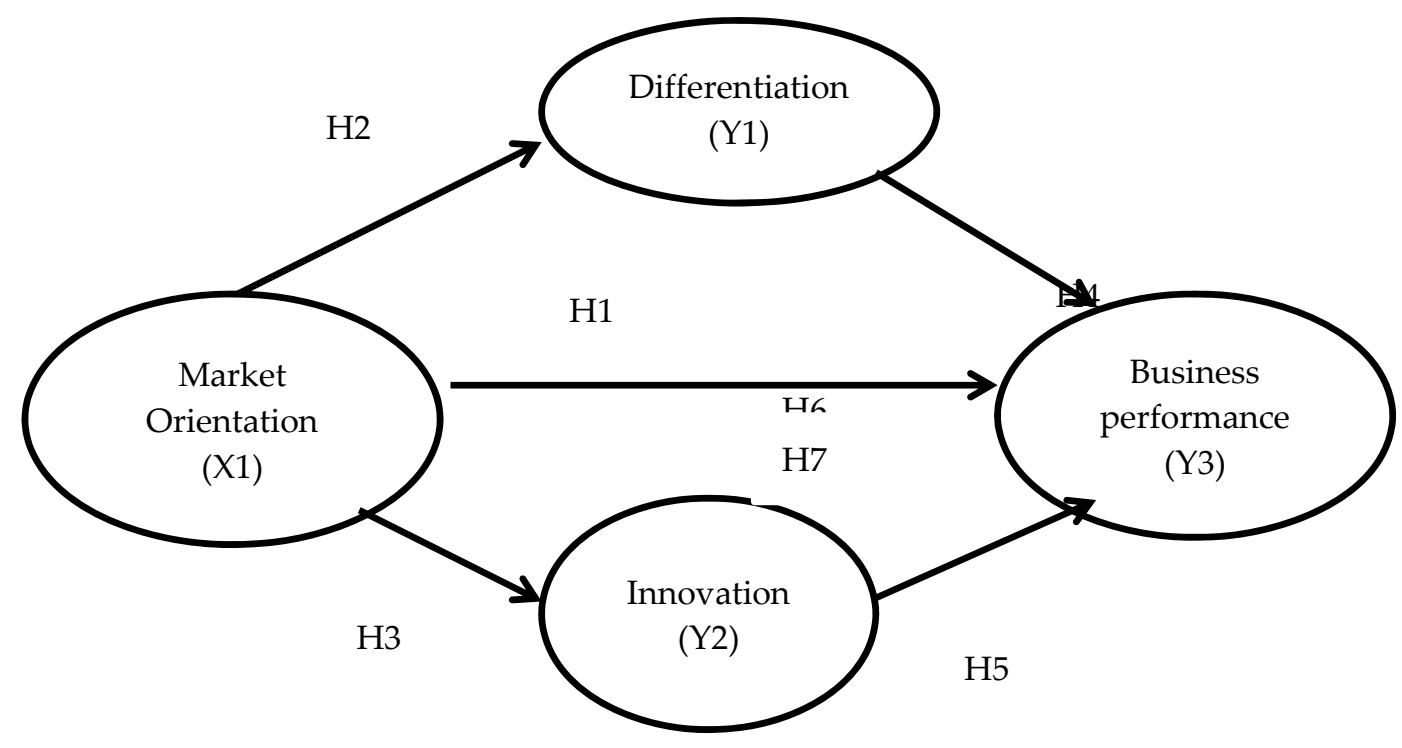

Figure 1. Conceptual Framework 


\section{Research Method}

This research was conducted on textile industry SMEs in Bali Province. The object of this research is the role of innovation and differentiation in mediating the relationship between market orientation and business performance in textile industry SMEs in Bali. Population and Sample The study population was the textile industry SMEs in Bali, which amounted to 60 business units. The sample size in this study was 60 entrepreneurs of textile industry SMEs. This sample size is representative because according to Ghozali (2006), PLS analysis requirements indicate that the number of samples taken does not have to be large. Likewise Solimun (2010) states that in PLS analysis the sample is not critical, as a benchmark sample size in PLS: 1) ten times the number of formative indicators (ignoring reflexive indicators), 2) ten times the number of structural paths (structural paths) in inner model and 3) small samples 30-50 or large samples of more than 200. The sampling technique uses random sampling, which is the census, where all populations are made as respondents.

\subsection{Data Collection and Data Measurement}

This study used interviews, namely conducting interviews with the owners of SMEs in the textile industry in Bali which were conducted using a questionnaire. The observation method is direct observation to the textile industry SMEs to find out the strategies applied in anticipating competition with modern retail. In this study using a Likert Scale. There are four variables in this study, namely, market orientation, differentiation strategies, innovation strategies, and business performance. Measurement of market orientation variables using ten indicators adopted from Utamningsih (2016), differentiation strategy variables using four indicators adopted from Kotler and Keller (2012), innovation strategy variables using three indicators adopted from Lin et al. (2012), as well as business performance variables using four indicators adopted from Al-Rfou (2012) and Guo (2002) that have been adapted to the object of research 
Journal of Business Management and Economic Research (JOBMER), vol.3, issue.6, pp.39-60

\section{Results}

\subsection{Data analysis technique}

This study uses SEM analysis techniques based on component or variance, namely PLS (Partial Least Square).

Table 1. PLS Validity and Reliability Test

\begin{tabular}{lccccc}
\hline & Outer & & Composit & \\
Variables and the Indicators & Loading & AVE & e & Cronbach \\
& & $*$ Reability & Alpha $\left.{ }^{* *}\right)$ \\
& & & $* *)$ & \\
\hline
\end{tabular}

\section{Market Orientation}

The company tries to listen to customers' $\mathbf{0 , 8 7 1}$

opinion. (X1.1)

The company tries to understand the needs 0,844

and wants of customers (X1.2)

The company focuses on customer 0,791

commitment $(\mathrm{X} 1.3)$

The company tries to be focused on providing $\quad 0,815$

customer satisfaction as a business strategy

$(\mathrm{X} 1.4)$

Focus on determining target customers. (X1.5) $\quad 0,870$

The sales workers try to collect information 0,780 related to competitors. (X1.6)

$0,688 \quad 0,956 \quad 0,933$


Journal of Business Management and Economic Research (JOBMER), vol.3, issue.6, pp.39-60

The company shares information related to 0,835

their competitors. (X1.7)

Integrates all functions $(\mathrm{X} 1.8)$

Cooperative culture exists between all 0,847

divisions within the company to create value-

added (X1.9)

The company emphasizes on good 0,785

communications. $(\mathrm{X} 1.10)$

Differentiation Strategy

The company has product differentiation. 0,862

(Y1.1)

The firm has personnel differentiation (Y1.2) $\quad 0,826$

The company has service differentiation. 0,908

$0,734 \quad 0,917 \quad 0,847$

The company has image differentiation (Y1.4) $\quad 0,826$

\section{Innovation Strategy}

The company offers more innovative products $\quad 0,910$

to customers (Y2.1)

The company performs modification on the 0,868

products offered to customers (Y2.2)

$0,820 \quad 0,932 \quad 0,879$

The company offers unique products that are 0,937

not offered by competitors (Y2.3) 
Journal of Business Management and Economic Research (JOBMER), vol.3, issue.6, pp.39-60

\section{Business Performance}

The company's sales growth increased over 0,868

the last five years. (Y3.1)

The company's profit growth achieved 0,831

increased over the last five years. (Y3.2)

$0,744 \quad 0,921 \quad 0,862$

Maintaining customer satisfaction from the 0,859

company's service. (Y3.3)

Maintaining the quality of textile products 0,891

offered to be better than competitors (Y3.4)

Source: Processed data results, 2018

Note: *) indicators are valid if the outer loadings and the AVE $>0,50$

${ }^{* *}$ ) indicators are reliable if the composite reliability and Cronbach alpha $>0,70$

Table 2. The Results of the Hypothesis Test using the Partial Least Square

\begin{tabular}{lccc}
\hline $\begin{array}{c}\text { Relationship Between } \\
\text { Variables }\end{array}$ & $\begin{array}{c}\text { Path } \\
\text { Coefficient }\end{array}$ & t-statistics & Description \\
\hline $\begin{array}{l}\text { Differentiation Strategy } \rightarrow \\
\text { Business Performance }\end{array}$ & 0,324 & 2,254 & Significant \\
\hline $\begin{array}{l}\text { Innovation Strategy } \rightarrow \\
\text { Business Performance }\end{array}$ & 0,307 & 2,404 & Significant \\
\hline Market Orientation $\rightarrow$ & 0,872 & 32,067 & Significant \\
Differentiation Strategy & & & \\
\hline
\end{tabular}


Journal of Business Management and Economic Research (JOBMER), vol.3, issue.6, pp.39-60

\begin{tabular}{lllll}
\hline $\begin{array}{l}\text { Market Orientation } \\
\text { Innovation Strategy }\end{array}$ & & 0,802 & 20,694 & Significant \\
\hline $\begin{array}{l}\text { Market Orientation } \\
\text { Business Performance }\end{array}$ & 0,838 & 20,468 & Significant \\
\hline
\end{tabular}

Source: Processed data results, 2018

Table 3. The Path Coefficient Results using the PLS Method

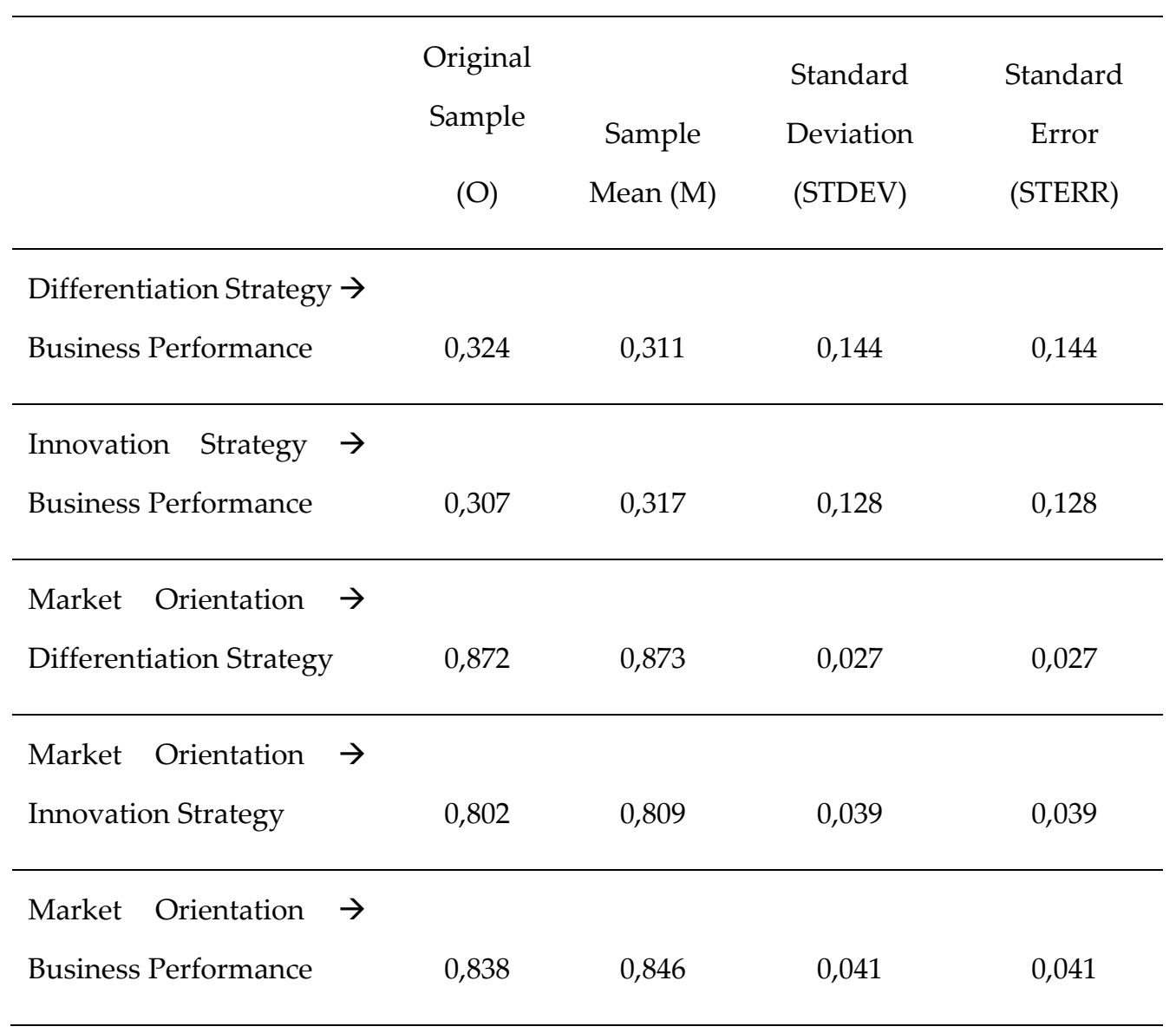

Source: Processed data results, 2018 
Journal of Business Management and Economic Research (JOBMER), vol.3, issue.6, pp.39-60

\section{Discussion}

\subsection{Market orientation has a positive influence on business performance}

The hypothesis test using the PLS approach for the direct influence of market orientation on business performance produced a path coefficient value of 0,838 and a t-statistics of 20,468. From the results, the t-statistics value is greater than 1,960 (t-table). Thus, it can be concluded that hypothesis 1 which states that market orientation has a positive and significant influence on business performance is accepted. This means that with a greater degree of market orientation, there will be an increase in the business performance of the company, vice versa.

This research result is in line with the research conducted by Pribadiyanto and Utami (2004), the study by Baker and Sinkula (1999), Lin et al. (2008), Nasution et al. (2011) and Alam (2013) which state that a greater degree of market orientation, reflected from customer orientation, sharing of market information, and interfunctional coordination, will positively influence the company's service quality. Likewise, the research conducted by Baker and Sinkula (1999) stated that market orientation has a significant relationship with company performance.

\subsection{Market orientation has a positive influence on differentiation strategy.}

The hypothesis test using the PLS approach regarding the direct influence of market orientation on differentiation strategy produced a path coefficient value of 0,872 and a t-statistics of 32,067 . From this results, the t-statistics is known to be greater than 1,960 (t-table). Thus, it can be concluded that hypothesis 2, which states that market orientation has a positive and significant influence on differentiation strategy is accepted. This means that a greater degree of market orientation will result in the improvement of the differentiation strategy implemented by the company.

This research result is in line with the research regarding the influence of market orientation on differentiation strategy conducted by Narver and Slater (1990), which stated that market orientation is the most effective and efficient organizational culture in forming the behaviors needed to create superior value for buyers and produce superior performance for the company. Likewise, the research conducted by Tjiptono and Chandra (2012) also stated that market orientation has a positive and significant influence on differentiation strategy. 


\subsection{Market orientation has an influence on innovation strategy}

The hypothesis test using the PLS approach, regarding the direct influence of market orientation on innovation strategy, produced a path coefficient value of 0,802 and a t-statistics of 20,964 . From this results, the t-statistics is known to be greater than 1,960 (t-table). Thus, it can be concluded that hypothesis 3, which states that market orientation has a positive and significant influence on innovation strategy, is accepted. This means that as the company becomes more oriented towards customers, the better the innovation strategy implemented by the company.

This result is in line with the research conducted by Nasution et al. (2011) and Rahab (2012) which stated that by integrating market orientation, innovation will improve. This means that having a deeper understanding of customer needs will allow the organization to improve their innovation culture. Mavondo et al. (2005) also identified innovation as the consequence of market orientation.

\subsection{The influence of differentiation strategy on business performance}

The hypothesis test using the PLS approach, regarding the direct influence of differentiation strategy on business performance, produced a path coefficient value of 0,324 and a t-statistics of 2,254. From this result, the $\mathrm{t}$-statistics is known to be greater than 1,960 (t-table). Thus, it can be concluded that hypothesis 4 which states that differentiation strategy has a positive and significant influence on business performance is supported. This means the better the differentiation strategy implemented in the company, the higher the business performance of that company.

This research result is consistent with the research conducted by Destyanti (2007) and Tampi (2015) which stated that differentiation strategy has a positive and significant influence on the business performance of Telkomsel. Kotler and Keller (2012) stated that differentiation strategy which comprises product differentiation, price differentiation, distribution differentiation, and image differentiation, is able to improve their business performance. 


\subsection{The influence of innovation strategy on business performance}

The hypothesis test using the PLS approach, regarding the direct influence of innovation strategy on business performance, produced a path coefficient value of 0,307 and a t-statistics of 2,404. From this result, the t-statistics is known to be greater than 1,960 (t-table). Thus, it can be concluded that hypothesis 5 which states that innovation strategy has a positive and significant influence on business performance is accepted. This means the better the innovation strategy, the higher the business performance of the company. This result is in line with the research conducted by Hilmi et al. (2010) and Rhee et al. (2010) that showed that innovation has a positive and significant influence on business performance.

\subsection{The Role of Differentiation Strategy and Innovation Strategy in Mediating the Influence of} Market Orientation on Business Performance

An intervening variable is a variable that influences the relationship between the predictor (independent) and the criterion/ dependent variable (Ghozali, 2005). The test is conducted using the procedure developed by Sobel (1982). The Sobel test is conducted by examining the indirect influence of $X$ on $Y$ through $M$, calculated by multiplying the path coefficient of $X \rightarrow M$ (a) with the path coefficient of $X \rightarrow M(b)$ or $a b$. The coefficient $a b=\left(c-c^{1}\right)$, in which $c$ is the influence of $X$ on $Y$ without controlling $\mathrm{M}$, while $\mathrm{c}^{1}$ is the coefficient of the influence of $\mathrm{X}$ on $\mathrm{Y}$ after controlling $\mathrm{M}$.

The standard error coefficient of a and $\mathrm{b}$ is written as $\mathrm{Sa}$ and $\mathrm{Sb}$, while the indirect effect standard error, Sab is calculated using the following formula:

$$
S a b=\sqrt{b^{2} S a^{2}+a^{2} S^{2}+S a^{2} S b^{2}}
$$

To test the significance of the indirect influence, the $t$-value of the ab coefficient is calculated using the following formula:

$$
t=\frac{a b}{S a b}
$$

The $t$-calculated value is compared with the $t$-table, and if the $t$-calculated is greater than the $t$-table value $(>1,96)$, it can be concluded that the mediation effect is significant. 


\subsection{The Role of Differentiation Strategy in Mediating the Influence of Market Orientation on} Business Performance

To examine the relationship between the intervening variable and the dependent variable, the Sobel test is used. The Sobel test result shows that the $t$ value is 5,391 which is greater than 1,96 . This means that the mediation parameter is significant. Thus, the model in which differentiation strategy mediates the influence of market orientation on business performance is accepted. This is consistent with the research conducted by Destyanti (2007) and Tampi (2015) in which market orientation has a positive and significant influence on differentiation strategy, while differentiation strategy has a positive and significant influence on business performance.

6.8 The role of innovation strategy in mediating the influence of market orientation on business performance

To examine the relationship between the intervening variable and the dependent variable, the Sobel test is used. The Sobel test result shows that the $t$ value $=4,884$ which is greater than 1,96 . This means that the mediation parameter is significant. Thus, the model in which innovation strategy mediates the influence of market orientation on business performance is accepted. This result is in line with the research conducted by Nasution et al. (2011) and Rhee et al. (2010) which stated that market orientation has a positive and significant influence on innovation strategy, while innovation strategy has a positive and significant influence on business performance.

\section{Research Implications}

\subsection{Practical Implications}

It is advisable for textile SME owners in Bali to try to listen to customer opinions, have service differentiation, offer unique products not provided by competitors, and maintain the quality of textile products offered in order to retain customer trust and loyalty towards the company. 


\subsection{Theoretical Implications}

This research clarifies the relationship between market orientation, differentiation strategy, innovation strategy, and the business performance variable which is applicable to the textile SME in Bali. The study also enriches the literature in the fields of business strategy.

\section{Conclusions and Recommendation}

Based on the discussions of the research results, it can be concluded that: 1) Market orientation has a positive and significant influence on business performance. 2) Market orientation has a positive and significant influence on differentiation strategy. 3) Market orientation has a positive and significant influence on innovation strategy. 4) Differentiation strategy has a positive and significant influence on business performance. 5) Innovation strategy has a positive and significant influence on business performance. 6) Differentiation strategy is able to partially mediate the relationship between market orientation and business performance. 7) Innovation strategy is able to partially mediate the relationship between market orientation and business performance.

The recommendations from this research are: 1) Textile SME should always try to collect information related to competitors, such as what products are salable in the market, the price of each product and the distribution channel, 2) textile SME must conduct personnel differentiation, such as having trained workers in order to compete well with other textile SME in Bali, 3) textile SME are expected to make modifications on the products they offer to customers in order to increase the profit gained by the company.

\section{References}

Alam, M.M., 2013, Effect of Market Orientation on Small Business Perormance in Small Town In Malaysia: An Emprical Study on Malaysian Small Firms, Journal of Strategic Marketing, Vol 1, No. 3. pp. $91-104$

Al-Rfou, A.N. 2012. Competition and Organizational Performance: Empirical Evidence from Jordanian Firms. Journal of Economics. Vol. 3 No. 1 (2012) pp. 13-17.

Baker, William E \& James M. Sinkula, 1999. The Synergistic Effect of Market Orientation and Learning 
Journal of Business Management and Economic Research (JOBMER), vol.3, issue.6, pp.39-60

Orientation on Organizational Performance, Journal of The Academy of Marketing Science, Vol 27, No 4. pp. 411-127.

Destianty, Marika. 2007. Implementasi Strategi Diferensiasi Untuk Meningkatkan Kinerja PT Telkomsel, Thesis, Universitas Airlangga, http://repository.unair.ac.id/7114/ Diakses tanggal 10 Pebruari 2018

Dinas Perindustrian dan Perdagangan Provinsi Bali. 2016. Rekapitulasi Data Industri Kecil dan Menengah Per Komoditi di Provinsi Bali.

Ferdinand, A. 2000. Manajemen Pemasaran : Sebuah Pendekatan Stratejik. Research Paper Series Konsentrasi Manajemen Pemasaran. Program Magister Manajemen Universitas Diponogoro, Semarang.

Ghozali, I. 2006, Structural Equation Model: Metode Alternatif dengan Partial Least Square (PLS), Badan Penerbit UNDIP, Semarang.

Guo, C., 2002, Market Orientation and business performance, a framework for service organizations, European Journal of Marketing, Vol 36 No 9/10 pp. 1154-1163.

Haksama, Nurhapna Setya. 2014. Pengaruh Perencanaan Strategis Terhada Kinerja Di Rumah Sakit - Effect of Strategic Planning on The HospitalPerformance. Journal Administrasi Kesehatan Indonesia, Vol 2, No. 2 April-Juni 2014.

Han, J.K., N.Kim., and R.K. Srivastva., 1998., Journal of Marketing. 62(4). pp. 30-45

Hult, G.T.M., Hurley, R.F. and Knight, G.A. 2004. Innovativeness: its antecedents and impact on business performance. Industrial Marketing Management, Vol. 33, No. 5, pp. 429-38

Hilmi, Mohd Faiz, T. Ramayah and Yanti Mustapha. 2010. Product and Process Innovativeness: Evidence From Malaysian SMEs. European Journal of Social Sciences. Vol. 16, No. 4, 547-555.

Jaworski, Bernard J. and Ajay K. Kohli. 1993. Market Orienta- tion: Antecedents and Consequences. Journal of' Marketing, 57 (July), 53-70.

Kohli, A.K. and Jaworski, B.J. 1990. Market Orientation: The Construct, Research Propositions, and Managerial Implications. Journal of Marketing, 54, 1-18. http://dx.doi.org/10.2307/1251866 
Journal of Business Management and Economic Research (JOBMER), vol.3, issue.6, pp.39-60

Kotler, Philip dan Kevin Lane Keller, 2012, Marketing Mangement 13, New Jersey : Pearson Prentice Hall, Inc.

Lin Ru Jen, Che, Roong H., Ting, Chiu, Y. 2012. Turning knowledge management into innovation in the high-tech industry, Industrial Management \& Data Systems, Vol 112 No1, pp. 42-63.

Lin, C.H., Peng, C.H., and Kao, D.T. 2008. The innovativeness effect of market orientation and learning orientation on business performance. International Journal of Manpower. Vol. 29 No. 8, pp. 752-772.

Mavondo, F.T., Chimhanzi, J., Stewart, J. 2005. Learning orientation and market orientation. Relationship with innovation, human resource practices and performance. European Journal of Marketing Vol.39 No. 11/12, pp. 1235-1263.

Nasution, H.N., Mavondo, F.T., Matanda, M.J., and Ndubisi, N.O, 2011, Entrepreneurship: its relationsship with market orientation and learning orientation and as antecedents to innovation and customer value, Industrial marketing Management. Vol. 40: p.336-345.

Narver, J.C. and Slater, S.F. 1990. The effect of a market orientation on business profitability. Journal of Marketing. Vol. 54 No. 4, pp. 20-35.

Ndubisi, N.O., and Iftikhar, K. 2012. Relationship between entrepreneurship, innovation and performance.Comparing small and medium-size enterprises. Journal of Research in Marketing and Entrepreneurship. Vol. 14 No. 2, 2012, pp. 214-236.

O,Cass, A., Ngo, L.V., 2011., Achieving customer satisfaction in services firms via branding capability and customer empowerment., Journal of Services Marketing, Vol. 25 Issue: 7, pp.489-496, https://doi.org/10.1108/08876041111173615

Pribadiyanto, N., M. Mudiantono., Utami, T.S. 2004. Analisis Faktor-Faktor Orientasi Pasar Yang Mempengaruhi Kualitas Layanan Dan Relevansinya Terhadap Kinerja Perusahaan, Jurnal Studi Manajemen dan Organisasi, Vol 1, No 2. pp.50-60.

Rahab. 2012. Innovativeness Model of Small And Medium Enterprises Based on Market Orientation and Learning Orientation: Testing Moderating Effect of Business Operation Mode. Procedia Economics and Finance 4, pp. $97-109$. 
Journal of Business Management and Economic Research (JOBMER), vol.3, issue.6, pp.39-60

Rhee, Jaehoon, Taekyung Park and Do Hyung Lee, 2010. Drivers of Innovativeness and Performance for Innovative SMEs in South Korea: Mediation of Learning Orientation. Journal Technovation. 30(1). pp. 65-75.

Setiawan, Antonius Singgih. 2016. Pengaruh Pemilihan Strategi Deferensiasi Terhadap Kinerja Keuangan (Studi Empiris Pada Perusahaan Manufaktur Food \& Beverages terdaftar di BEI). Jurnal Akuntansi, Vol XX, No. 01, Januari 2016. pp. 104-116.

Sobel, J. 1985.The Review of Economic Studies, Volume 52, Issue 4, October 1985, Pages 557573,https://doi.org/10.2307/2297732

Solimun. 2010. Analisis Multivariat Pemodelan Struktural, Metode Partial Square-PLS, Malang : CV Citra.

Tampi, Nicky Hannry Ronaldo, 2015, Analisis Strategi Diferensiasi Produk, Diferensiasi Layanan Dan Diferensiasi Citra Terhadap Keunggulan Bersaing Dan Kinerja Pemasaran (Studi Pada PT.Telkomsel Grapari Manado), Jurnal EMBA, Vol.3 No.4. Hal. 68-81.

Tjiptono, Fandy, 2008, Strategi Pemasaran, Edisi 3, Yogyakarta : Andi

Tjiptono, Fandy dan Gregorius Chandra, 2012, Pemasaran Strategik, Yogyakarta : Andi.

Zhou, K., Yim, C.K., dan Tse, D.K., 2005, The Efeect of strategic Orientations on Technology-and Market-Based Breakthrough Innovations. Journal of Marketing. Vol 69 (April 2005).pp. 42-60. 